\title{
The estimation of emissions from internal combustion engines fuelled by bioethanol
}

\begin{abstract}
The use of bioethanol fuels is one of the most efficient methods of reduction of toxic emission and reduction of engine noxiousness to the environment at the same time. The ecological effects of the bioethanol fuel application fuelling spark ignition engines and self-ignition engines are presented in the paper. The paper presents original, not yet published, test results of the Scania DC9 E02 270 engine.
\end{abstract}

Key words: toxic emissions, combustion engines, bioethanol fuels

\section{Ocena emisji zanieczyszczeń z silników spalinowych zasilanych paliwami bioetanolowymi}

Zastosowanie paliw bioetanolowych stanowi jedna z najskuteczniejszych metod zmniejszenia ucią̇liwości silników spalinowych dla środowiska ze względu na emisję zanieczyszczeń. W pracy przedstawiono ekologiczne skutki zastosowania paliw bioetanolowych do zasilania silników o zapłonie iskrowym i zapłonie samoczynnym. Przedstawiono oryginalne, niepublikowane dotychczas wyniki badań silnika Scania DC9 EO2 270.

Słowa kluczowe: emisja zanieczyszczeń, silniki spalinowe, paliwa bioetanolowe

\section{Introduction}

The most important examples of adverse impact on the human environment, related to toxic emissions of combustion engines include: [4-7]:

- Local hazards in the form of toxic emissions dangerous to the health of people and animals,

- Global hazards with particular attention focused on the greenhouse effect in the atmosphere,

- Local hazards in the form of tropospheric ozone precursors facilitating the photochemical smog creation.

Substances that are most damaging to human health and contained in the engine exhaust gases are [4-7]:

- Carbon monoxide,

- Organic compounds, particularly heavy organic compounds,

- Nitrogen oxides,

- Particles.

The most important greenhouse gas among the ones occurring as a result of combustion engine operation is carbon dioxide, originating from fossil (i.e. mineral) fuels - most of all due to the dominating quantity of this compound in the exhaust gases [4-7].

The basic precursors of tropospheric ozone are nitrogen oxides and volatile organic compounds [2, 3, 9].

The most important pro-ecological measures related to toxic emissions by combustion engines include [1, 4-12]:

- improvement of combustion engines in terms of their general efficiency and toxic emissions,

- development of fuels; above all, the use of alternative fuels, of which most attention is paid to renewable fuels, i.e. biofuels,

- improvement of vehicle and machine power unit solutions, in terms of efficiency - hybrid systems in particular.

\section{Wprowadzenie}

Najważniejszymi szkodliwymi oddziaływaniami na środowisko ludzi, związanymi z emisją zanieczyszczeń z silników spalinowych, są [4-7]:

- zagrożenia lokalne w postaci emisji zanieczyszczeń szkodliwych dla zdrowia ludzi i zwierząt,

- zagrożenia globalne, spośród których szczególną wagę przywiązuje się do zjawiska cieplarnianego w atmosferze,

- zagrożenia lokalne w postaci emisji prekursorów ozonu troposferycznego, sprzyjających powstawaniu zjawiska smogu fotochemicznego.

Substancjami najbardziej szkodliwymi dla zdrowia ludzi, zawartymi w spalinach silników, są [4-7]:

- tlenek węgla,

- związki organiczne, a szczególnie ciężkie związki organiczne,

- tlenki azotu,

- cząstki stałe.

Najważniejszym gazem cieplarnianym spośród powstających w związku z eksploatacją silników spalinowych jest dwutlenek węgla, pochodzący ze źródeł kopalnych (czyli pochodzenia mineralnego) - przede wszystkim ze względu na dominującą ilość tego związku w spalinach [4-7].

Podstawowymi prekursorami ozonu troposferycznego są tlenki azotu i lotne związki organiczne [2, 3, 9].

Do najważniejszych działań proekologicznych związanych z emisją zanieczyszczeń z silników spalinowych zalicza się [1, 4-12]:

- doskonalenie silników spalinowych ze względu na ich sprawność ogólną i na emisję zanieczyszczeń,

- rozwój paliw; przede wszystkim zastosowanie paliw alternatywnych, wśród których szczególną wagę przywiązuje się do paliw odnawialnych, czyli biologicznych, 
The best improvement of the ecological properties of combustion engines in terms of toxic emissions is obtained thanks to the use of biofuels. It is particularly noticeable when initiatives are taken up, in order to reduce fossil carbon dioxide emissions. Other methods of this emission reduction are incomparable to the use of biofuels. Therefore, international programs clearly set the increased biofuel share in the fuels used by combustion engines $[4,5,7]$.

Among the biofuels possible to be used now and within the coming dozen of years, there are some hopes related to bioethanol $[1,4,5,7-12]$. This is not only the result of viable and extensive potential of bioethanol production from numerous low-value materials, including waste $[4,5,7]$.

\section{Bioethanol fuels for spark-ignition engines}

In spark-ignition engines bioethanol is applied as: - gasoline additive in the amount not exceeding 5\% v/v $(\mathrm{v} / \mathrm{v}$ - volumetric shares $)$ - such fuel is not considered a biofuel,

- gasoline additive in the amount above $5 \% \mathrm{v} / \mathrm{v}-$ fuel is considered a biofuel,

- E85 fuel, representing a mixture of bioethanol $(85 \% \mathrm{v} / \mathrm{v})$ and gasoline,

- tests on the E100 [bioethanol with improving additives] fuel are in progress. Bioethanol can be used as an additive to gasoline, also in the form of derivative compounds, e.g. ether.

The test results on toxic emissions from engines powered by bioethanol fuels [1, 5, 9-12] allow to expect a lot as regards the fuels. An example can be the test results of Chrysler Caravan with a multi-fuel engine, so-called flexifuel, fuelled by reformed gasoline - $\mathrm{G}$ and bioethanol E85 [9]. Fig. 1-4 present toxic emissions and fuel consumption test results.

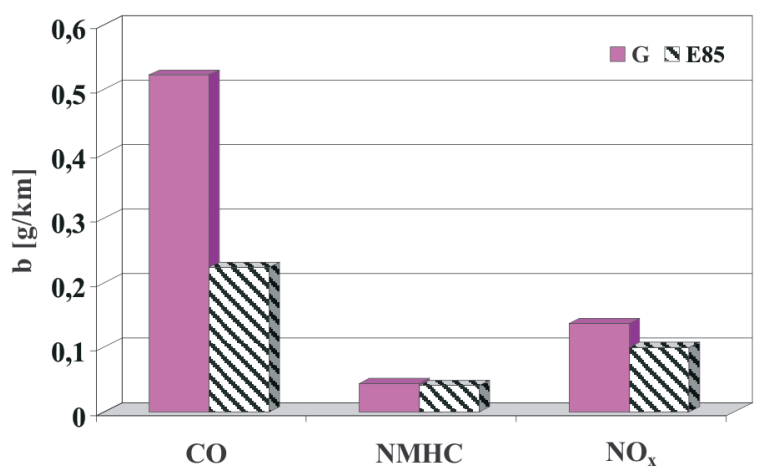

Fig. 1. Road emission b of $\mathrm{CO}, \mathrm{NMHC}$ and $\mathrm{NO}_{\mathrm{x}}$ for the fuels tested Rys. 1. Emisja drogowa b tlenku węgla CO, niemetanowych węglowodorów NMHC i tlenków azotu $\mathrm{NO}_{x}$ dla badanych paliw

The application of the bioethanol fuel in multi-fuel engines adapted to the combustion of mixtures of gasoline and the E85 fuel in any proportions enables the achievement of measurable ecological benefits. Obviously, the application of the E85 bioethanol fuel to power the engine must cause increased fuel consumption because the calorific value of ethanol is by ca. $40 \%$ lower than that of gasoline.
- doskonalenie rozwiązań zespołów napędowych pojazdów i maszyn ze względu na sprawność, przede wszystkim układów hybrydowych.

Najlepszą poprawę właściwości ekologicznych silników spalinowych ze względu na emisję zanieczyszczeń uzyskuje się dzięki zastosowaniu paliw biologicznych. Jest to szczególnie zauważalne przy podejmowaniu inicjatyw na rzecz zmniejszenia emisji dwutlenku węgla kopalnego. Inne metody zmniejszenia tej emisji są nieporównywalne $\mathrm{z}$ zastosowaniem biopaliw. $\mathrm{Z}$ tego powodu międzynarodowe programy jednoznacznie ustanawiają zwiększanie udziału biopaliw w paliwach zużywanych przez silniki spalinowe $[4,5,7]$.

Spośród biopaliw, realnie możliwych do zastosowania obecnie oraz w ciągu najbliższych kilkunastu lat, szczególne nadzieje wiąże się $\mathrm{z}$ bioetanolem $[1,4,5,7-12]$. Wynika to nie tylko z obiektywnie bardzo dużych możliwości zmniejszenia emisji zanieczyszczeń dzięki jego zastosowaniu, lecz także z możliwości produkcji bioetanolu z wielu surowców mało wartościowych, m.in. odpadowych [4, 5, 7].

\section{Paliwa bioetanolowe do silników o zapłonie iskrowym}

W silnikach o zapłonie iskrowym bioetanol znajduje zastosowanie jako:

- dodatek do benzyny w ilości nie większej niż 5\% v/v (v/v - udziały objętościowe) - paliwo takie nie jest uznawane za biopaliwo,

- dodatek do benzyny w ilości większej niż 5\% v/v - paliwo jest uznawane za biopaliwo,

- paliwo E85, stanowiące mieszaninę bioetanolu (udział $85 \% \mathrm{v} / \mathrm{v}$ ) oraz benzyny,

- w fazie badań jest paliwo E100, stanowiące bioetanol z dodatkami uszlachetniającymi.

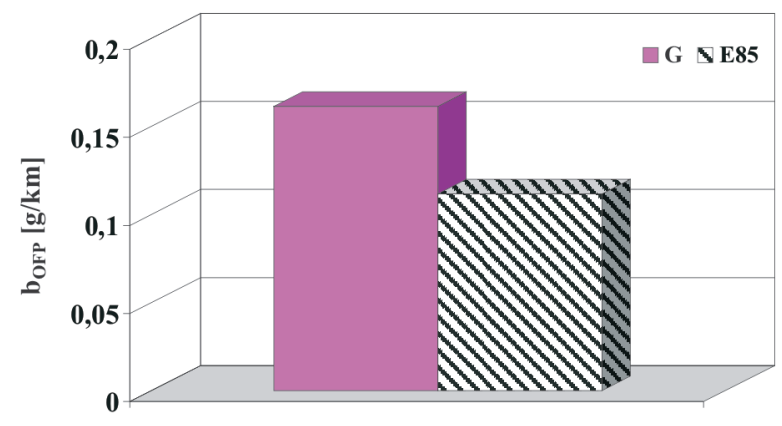

Fig. 2. Road emission of potential ozone bOFP for the fuels tested Rys. 2. Emisja drogowa potencjalnego ozonu bOFP dla badanych paliw

Bioetanol może być użyty jako dodatek do benzyny również w postaci związków pochodnych, np. eteru.

Wyniki badań emisji zanieczyszczeń z silników zasilanych paliwami bioetanolowymi [1, 5, 9-12] pozwalają na wiązanie dużych nadziei z tymi paliwami. Przykładem są wyniki badań samochodu Chrysler Caravan z silnikiem wielopaliwowym, tzw. flexi-fuel, zasilanym paliwami: benzyną reformowaną - G i paliwem bioetanolowym E85 [9]. 


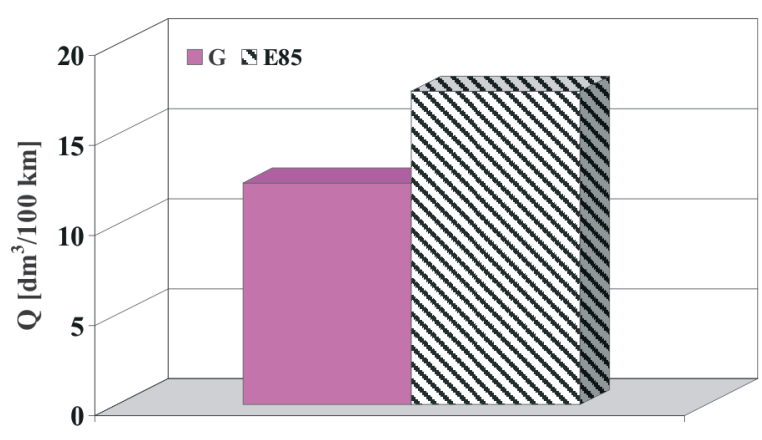

Fig. 3. Operating consumption of fuels Q Rys. 3. Eksploatacyjne zużycie badanych paliw $Q$

\section{Bioethanol fuel for self-ignition engines}

The E95 fuel with specification developed at SEKAB AB (tab. 1 [7]) is used to power self-ignition engines.

The application of the E95 fuels requires the use of a special engine. The only manufacturer of such engines is Scania. Table 2 presents the basic parameters of the Scania DC9 E02 270 engine [7].

The Scania DC9 E02 270 engine is fitted with a pumpnozzle fuelling system. A 4-valve timing gear per each cylinder was applied. As a standard, exhaust gas recirculation and oxidation catalyst were used in the engine.

Table 1. Composition of E95 fuel

Tabela 1. Skład paliwa E95

\begin{tabular}{|l|c|}
\hline \multicolumn{1}{|c|}{$\begin{array}{c}\text { Fuel component/ } \\
\text { sktadnik paliwa }\end{array}$} & $\begin{array}{c}\text { Weight content/ } \\
\text { zawartość masowa }\end{array}$ \\
\hline Ethanol 95\% v/v/etanol 95\% v/v & $92.2 \%$ \\
\hline Ignition activator/aktywator zapłonu & $5 \%$ \\
\hline MTBE ether/eter MTBE & $2.3 \%$ \\
\hline Isobuthane/izobutanom & $0.5 \%$ \\
\hline Corrosion inhibitor/inhibitor korozji & $90 \mathrm{ppm}$ \\
\hline
\end{tabular}

Table 2. Basic parameters of Scania DC9 E02 270

Tabela 2. Podstawowe parametry silnika Scania DC9 E02 270

\begin{tabular}{|l|c|}
\hline \multicolumn{1}{|c|}{ Size/wielkość } & Value/wartość \\
\hline Displacement volume/objętość skokowa & $8.7 \mathrm{dm}^{3}$ \\
\hline Number of cylinders/liczba cylindrów & 5 \\
\hline Compression ratio/stopień sprężania & 28 \\
\hline Rated power/moc znamionowa & $199 \mathrm{~kW}(270 \mathrm{KM})$ \\
\hline $\begin{array}{l}\text { Rated engine speed/znamionowa prędkość } \\
\text { obrotowa }\end{array}$ & $1900 \mathrm{~min}^{-1}$ \\
\hline Maximum torque/maksymalny moment obrotowy & $1200 \mathrm{~N} \cdot \mathrm{m}$ \\
\hline $\begin{array}{l}\text { Engine speed at maximum torque/prędkość } \\
\text { obrotowa maksymalnego momentu obrotowego }\end{array}$ & $(1100-1400) \mathrm{min}^{-1}$ \\
\hline
\end{tabular}

Fig. 5 and 6 present the relative difference between the EURO 4 and EURO 5 limits and the unit toxic emission in the tests: static ESC and dynamic ETC by the Scania DC9 E02 270 engine $[5,7]$. The THC emission (THC - total hydrocarbons) is determined for the ESC test, while for the NMHC (NMHCnon-methane hydrocarbons) is determined for the ETC test.

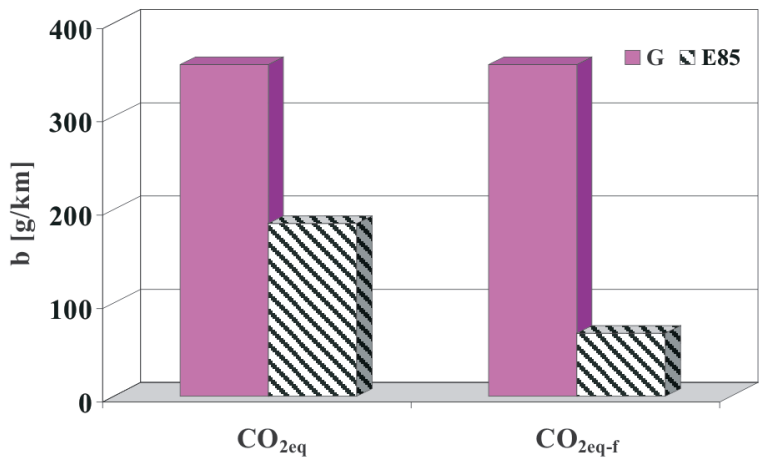

Fig. 4. Reduced road emission of $\mathrm{CO}_{2 \mathrm{eq}}$ carbon dioxide and $\mathrm{CO}_{2 \mathrm{eq}-\mathrm{f}}$ fossil carbon dioxide for the fuels tested

Rys. 4. Zredukowana emisja drogowa b dwutlenku węgla $\mathrm{CO}_{2 e q}$ i dwutlenku węgla kopalnego $\mathrm{CO}_{2 e q-f}$ dla badanych paliw

Na rysunkach 1-4 przedstawiono wybrane wyniki badań emisji zanieczyszczeń i zużycia paliwa.

Zastosowanie paliwa bioetanolowego do zasilania silników wielopaliwowych przystosowanych do spalania mieszanek benzyny i paliwa E85 w dowolnych proporcjach umożliwia osiągnięcie wymiernych korzyści ekologicznych. Oczywiście zastosowanie do zasilania paliwa bioetanolowego E85 musi powodować zwiększenie zużycia paliwa, ponieważ wartość opałowa etanolu jest o około $40 \%$ mniejsza niż benzyny.

\section{Paliwo bioetanolowe do silników o zapłonie samoczynnym}

Do zasilania silników o zapłonie samoczynnym jest wykorzystywane paliwo E95 o specyfikacji opracowanej w firmie SEKAB AB (tab. 1 [7]).

Zastosowanie paliwa E95 wymaga użycia specjalnego silnika. Jedynym producentem takich silników jest Scania. W tabeli 2 przedstawiono podstawowe parametry silnika Scania DC9 E02 270 [7].

Silnik Scania DC9 E02 270 jest wyposażony w układ zasilania z pompowtryskiwaczami. Zastosowano w nim rozrząd z czterema zaworami na każdy cylinder. Standardowo zastosowano w silniku recyrkulację spalin oraz utleniający reaktor katalityczny.

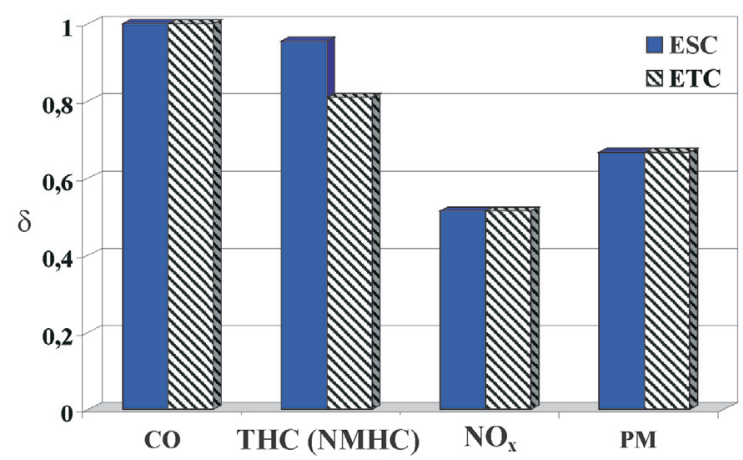

Fig. 5. Relative difference $\delta$ between the EURO 4 limits and unit toxic emissions in the ESC and ETC tests of the Scania DC9 E02 270 engine Rys. 5. Względna różnica $\delta$ między limitami EURO 4 i emisja jednostkowa zanieczyszczeń w testach ESC i ETC z silnika Scania DC9 E02 270 


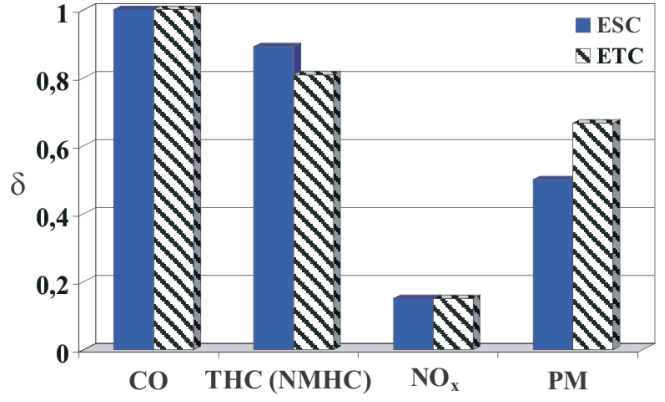

Fig. 6. Relative difference $\delta$ between the EURO 5 limits and unit toxic emissions in the ESC and ETC tests of the Scania DC9 E02 270 engine

Rys. 6. Względna różnica $\delta$ między limitami EURO 5 i emisja jednostkowa zanieczyszczeń w testach ESC i ETC z silnika Scania DC9 E02 270

The drawings shows a significant reserve of unit toxic emissions in relation to the EURO 5 limits.

The potential ozone emission was estimated in virtue of Carter's theory [2, 3] (Fig. 7). The potential ozone emission of a bioethanol engine is also significantly lower that that of a classic engine and it is below the unit toxic emission limits.

Like in the case of spark ignition engines, the application of the E95 fuel causes an increased fuel consumption, due to lower calorific value of the E95 fuel than that of the diesel oil. The calorific value ratio for the E95 fuel and for the diesel oil is 0.60 . An efficient engine estimation method is to compare their general value. Fig. 8 presents the external speed characteristic of the engines: bioethanol DSI 9 E01 and classic DC9 01 engine fuelled by diesel oil, comparable to the DSI 9 E01 engine. The characteristic was determined through the test results made in the R\&D center of Scania AB in Södertelje.

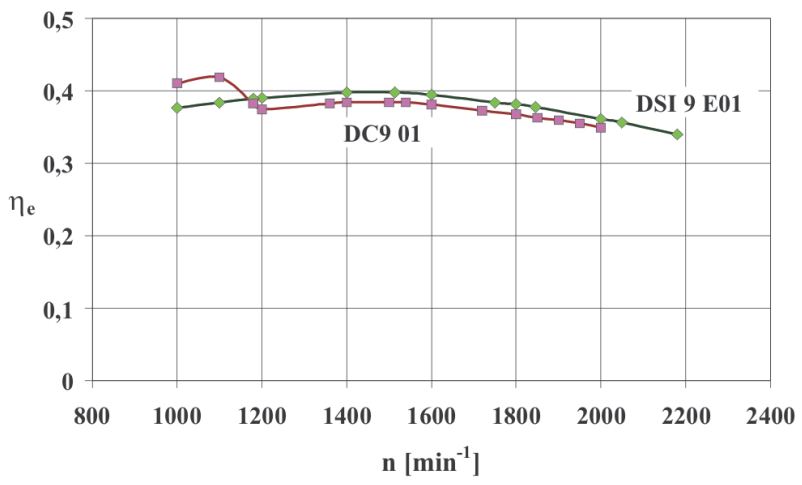

Fig. 8. External speed characteristic of the general efficiency $\eta_{e}$ of the engines: bioethanol DSI 9 E01 and classic DC9 01

Rys. 8. Zewnętrzna charakterystyka prędkościowa sprawności ogólnej $\eta_{e}$ silników: bioetanolowego DSI 9 E01 oraz klasycznego DC9 01

The characteristic suggests that the general efficiency of both engines is comparable and, in the engine speed range most often applied in operation is even higher for a bioethanol engine.

\section{Conclusions}

The favorable properties of bioethanol fuels for sparkignition engines have been known for almost 100 years
Na rysunkach 5 i 6 przedstawiono względną różnicę między limitami EURO 4 i EURO 5 a emisją jednostkową zanieczyszczeń w testach: statycznym ESC i dynamicznym ETC z silnika Scania DC9 E02 270 [5, 7]. Emisja węglowodorów THC (THC - total hydrocarbons) jest wyznaczana dla testu ESC, zaś niemetanowych węglowodorów NMHC (NMHC - non-methane hydrocarbons) dla testu ETC.

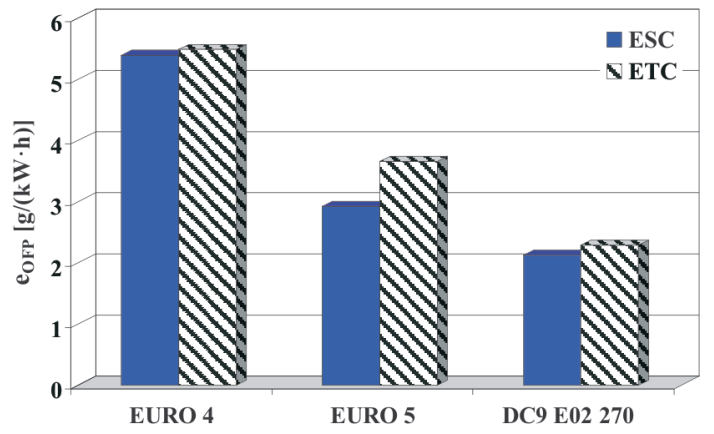

Fig. 7. Unit emission of potential ozone bOFP in the ESC i ETC tests, according to the EURO 4 and EURO 5 limits and of the Scania DC9 E02 270 engine

Rys. 7. Emisja jednostkowa potencjalnego ozonu bOFP $w$ testach ESC i ETC zgodnie z limitami EURO 4 i EURO 5 oraz z silnika Scania DC9 E02 270

Na rysunkach tych widoczny jest znaczny zapas emisji jednostkowej zanieczyszczeń w stosunku do limitów nawet EURO 5.

Na podstawie teorii Cartera [2, 3] oszacowano emisję potencjalnego ozonu (rys. 7). Również w przypadku potencjalnego ozonu emisja z silnika bioetanolowego jest znacznie mniejsza niż z silnika klasycznego i niż wynika to z limitów emisji jednostkowej zanieczyszczeń.

Podobnie jak w przypadku silników o zapłonie iskrowym, zastosowanie paliwa E95 powoduje zwiększenie zużycia paliwa z powodu mniejszej wartości opałowej paliwa E95 niż oleju napędowego. Stosunek wartości opałowej dla paliwa E95 i dla oleju napędowego wynosi 0,60. Skuteczną metodą oceny silników jest porównanie ich sprawności ogólnej. Na rysunku 8 przedstawiono zewnętrzną charakterystykę prędkościową silników: bioetanolowego DSI 9 E01 oraz klasycznego zasilanego olejem napędowym DC9 01, stanowiącego silnik porównywalny do DSI 9 E01. Charakterystykę wyznaczono na podstawie wyników badań wykonanych w ośrodku badawczo-rozwojowym koncernu Scania AB w Södertelje.

Z charakterystyki tej wynika, że sprawność ogólna obydwu silników jest porównywalna, a nawet, w zakresie prędkości obrotowej najczęściej wykorzystywanej w eksploatacji, większa dla silnika bioetanolowego.

\section{Wnioski}

Korzystne właściwości paliw bioetanolowych do silników o zapłonie iskrowym są znane od prawie 100 lat. W ostatnich kilkunastu latach nastąpił rozwój metod zasilania silników o zapłonie samoczynnym paliwem bioetanolowym. 
now. The development of self-ignition engines fuelled with bioethanol has grown only in recent years.

The most important ecological effects of using bioethanol fuels in combustion engines are as follows:

1. Considerable reduction of carbon dioxide emission.

2. Significant reduction of hydrocarbon emission, poly-cyclic aromatic hydrocarbon emissions, in particular.

3. Significant reduction of nitrogen oxides. This property is of particular value - among the biofuels used at present, only bioethanol fuels give the possibility to reduce nitrogen oxide emissions, in case of application of vegetable oil esters.

4. Considerable reduction of particle emissions.

5. Possibility to increase aldehyde emissions. This inconvenience is relatively easy to be corrected - the application of oxidation catalysts is an efficient method of aldehyde oxidation.

6. Reduction of sulfur compound emissions.

7. Restricted emission of carbon dioxide in a closed circle of production and fuel exploitation.

8 . Very good biodegradability.

The favorable properties of bioethanol fuels for sparkignition engines have been known for almost 100 years. The last dozen of years signify the development of fuelling methods for self-ignition engines with bioethanol fuel.

The toxic emission test results of engines fuelled with bioethanol fuels prove that - in addition to the obvious reduction of fossil carbon dioxide emission - there is a possibility to significantly reduce the emissions of toxic components damaging to the health of people and animals, this includes the reduction of tropospheric ozone precursors, contributing to the occurrence of the photochemical smog phenomenon.

Artykut recenzowany
Najważniejszymi ekologicznymi skutkami zastosowania paliw bioetanolowych do zasilania silników spalinowych są:

1. Bardzo duże zmniejszenie emisji tlenku węgla.

2.Znaczne zmniejszenie emisji węglowodorów, w tym szczególnie zmniejszenie emisji wielopierścieniowych węglowodorów aromatycznych.

3.Znaczne zmniejszenie emisji tlenków azotu. Jest to szczególnie cenna właściwość - spośród stosowanych obecnie biopaliw tylko paliwa bioetanolowe dają możliwość zmniejszenia emisji tlenków azotu; w przypadku stosowania estrów olejów roślinnych następuje zwiększenie emisji tlenków azotu.

4. Bardzo duże zmniejszenie emisji cząstek stałych.

5. Możliwość zwiększenia emisji aldehydów. Niedogodność ta jest stosunkowo łatwa do usunięcia - zastosowanie utleniających reaktorów katalitycznych jest skuteczną metodą utlenienia aldehydów, które są bardzo reaktywnymi związkami.

6.Zmniejszenie emisji związków siarki.

7. Ograniczenie emisji dwutlenku węgla w zamkniętym cyklu powstawania i eksploatacji paliw.

8. Bardzo dobra degradowalność biologiczna.

Korzystne właściwości paliw bioetanolowych do silników o zapłonie iskrowym są znane od prawie 100 lat. Ostatnie kilkanaście lat to rozwój metod zasilania silników o zapłonie samoczynnym paliwem bioetanolowym.

Wyniki badań emisji zanieczyszczeń z silników zasilanych paliwami bioetanolowymi wykazują, że - oprócz oczywistego zmniejszenia emisji dwutlenku węgla kopalnego - istnieje możliwość znacznego zmniejszenia emisji zanieczyszczeń szkodliwych dla zdrowia ludzi i zwierząt, w tym również zmniejszenia emisji prekursorów ozonu troposferycznego, przyczyniającego się do powstawania zjawiska smogu fotochemicznego.

[8] Cole R.L., Poola R.B., Sekar R., Schaus J.E., McPartlin P.: Effects of Ethanol Additives on Diesel Particulate and $\mathrm{NO}_{x}$ Emissions. SAE 2001-01-1937.

[9] Environment Canada: Mobile Source Emissions \& Biofuels: An Overview of Selected Canadian Federal R\&D. Ottawa 2007.

[10] Guerrieri D.A., Caffrey P. J., Rao V.: Investigation into the Vehicle Exhaust Emissions of High Percentage Ethanol Blends. SAE 950777.

[11] Hammel-Smith C., Fang J., Powders m., Aabakken J.: Issues Associated with the Use of Higher Ethanol Blends (E17-E24). National Renewable Energy Laboratory. NREL/TP-51032206. October 2002.

[12] Kelly K.J., Beiley B.K., Coburn T.C., Clark W., Lissiuk P.: Federal Test Procedure Emissions Test Results from Ethanol Variable-Fuel Vehicle Chevrolet Luminas. SAE 961092.

Mr Zdzisław Chłopek, DSc, MEng - Professor in the Faculty of Vehicles and Working Machines at Warsaw University of Technology.

Dr hab. inż. Zdzistaw Chtopek- profesor na Wydziale Samochodów i Maszyn Roboczych Politechniki Warszawskiej.

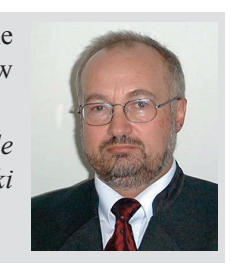

